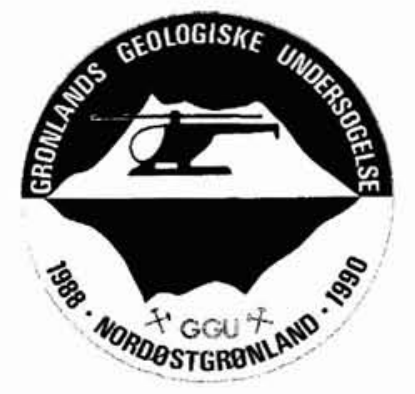

\title{
Reaction of Precambrian high-grade gneisses to mid-crustal ductile deformation in western Dove Bugt, North-East Greenland
}

\author{
Brian Chadwick and Clark R. L. Friend
}

\begin{abstract}
Mid-crustal deformation of an Early Proterozoic high-grade gneiss complex in western Dove Bugt gave rise to at least two sets of nappes. Structures in mylonites in low-angle ductile shear zones associated with the younger nappes indicate north-easterly-directed displacements. The nappes and mylonites are folded by upright to inclined folds that verge north-west and which appear to be associated with décollements that dip south-east. Hornblende, sillimanite and anatectic partial melts that developed with the nappes, mylonites and younger folds show that deformation took place under amphibolite facies conditions.

Several lines of evidence suggest that the younger nappes, the mylonites and the upright to inclined folds formed during the Caledonian orogeny. Some pre-Caledonian deformation may be represented by the oldest isoclinal folds. Numerous, small-scale, ductile extensional shear zones and more brittle fractures that were superimposed across the Caledonian structures are believed to have formed during orogen-parallel collapse which may be related to Devonian basin development farther south in central East Greenland. Younger faults and major joints are correlated with Carboniferous, Mesozoic and Tertiary basin development in North-East Greenland.
\end{abstract}

B. C., Earth Resources Centre, University of Exeter, Exeter EX4 4QE, U.K.

C.R.L.F., Department of Geology, Oxford Brookes University, Oxford OX3 OPB, U.K.

The Dove Bugt region, which lies within the internal part of the Caledonides of North-East Greenland (Fig. 1), is dominated by Precambrian high-grade orthogneisses and intersheeted supracrustal rocks that were variably deformed by mid-crustal processes. The region is separated from gneisses and cover rocks of the Caledonian foreland in Dronning Louise Land to the west by an imbricate zone, marking a major thrust, and the Storstrømmen shear zone (SSZ), a belt of mylonites at least $400 \mathrm{~km}$ long and at least $8 \mathrm{~km}$ wide (Holdsworth \& Strachan, 1991). This paper presents a detailed account of field relationships and it reviews evidence for the timing of the mid-crustal deformation of the high-grade gneiss complex in western Dove Bugt. The effects and significance of post-Caledonian brittle faulting in western Dove Bugt are also discussed briefly.

The oldest orthogneisses in Dove Bugt are grey polyphase migmatites which intruded and disrupted a major suite of supracrustal rocks with associated gabbros and coarse megacrystic anorthosites. Isotopic age data (Kalsbeek et al., 1993) indicate that significant proportions of the protoliths of the orthogneisses were derived from Archaean sialic crust and were emplaced as newlyformed crust during the Early Proterozoic, probably in a period of plate collision. The supracrustal units and enclaves within the grey polyphase orthogneisses include cordierite- and sillimanite-bearing paragneisses, amphibolites and calcitic marbles. One of the marble units is characterised by musgravite, a rare beryllium oxide (Chadwick et al., 1993). Younger orthogneisses include grey homogeneous gneisses, mixed orthogneisses, pink hornblendic gneisses and pink porphyritic and augen granitoid gneisses (Chadwick \& Friend, 1991). Many of these gneisses, particularly the pink varieties, occur as persistent, sub-concordant sheets which, with the sheets of supracrustal rocks, form useful markers which help to elucidate the regional structure. Zircons from one of these late sheets of pink porphyritic granitoid gneiss in Hellefjord (Fig. 2) have yielded a SHRIMP U/Pb isotopic age of $1739 \pm 11 \mathrm{Ma}$ (Kalsbeek et al., 1993).

Chadwick \& Friend (1991) provided a preliminary outline of the structure and metamorphism of the highgrade gneiss complex in western Dove Bugt, describing the regional structure in terms of two nappe-forming events and a younger period of upright to inclined folding with north-westerly vergence. All these events occurred after emplacement of sheets of pink granite that are now represented by the porphyritic, augen and hornblendic 


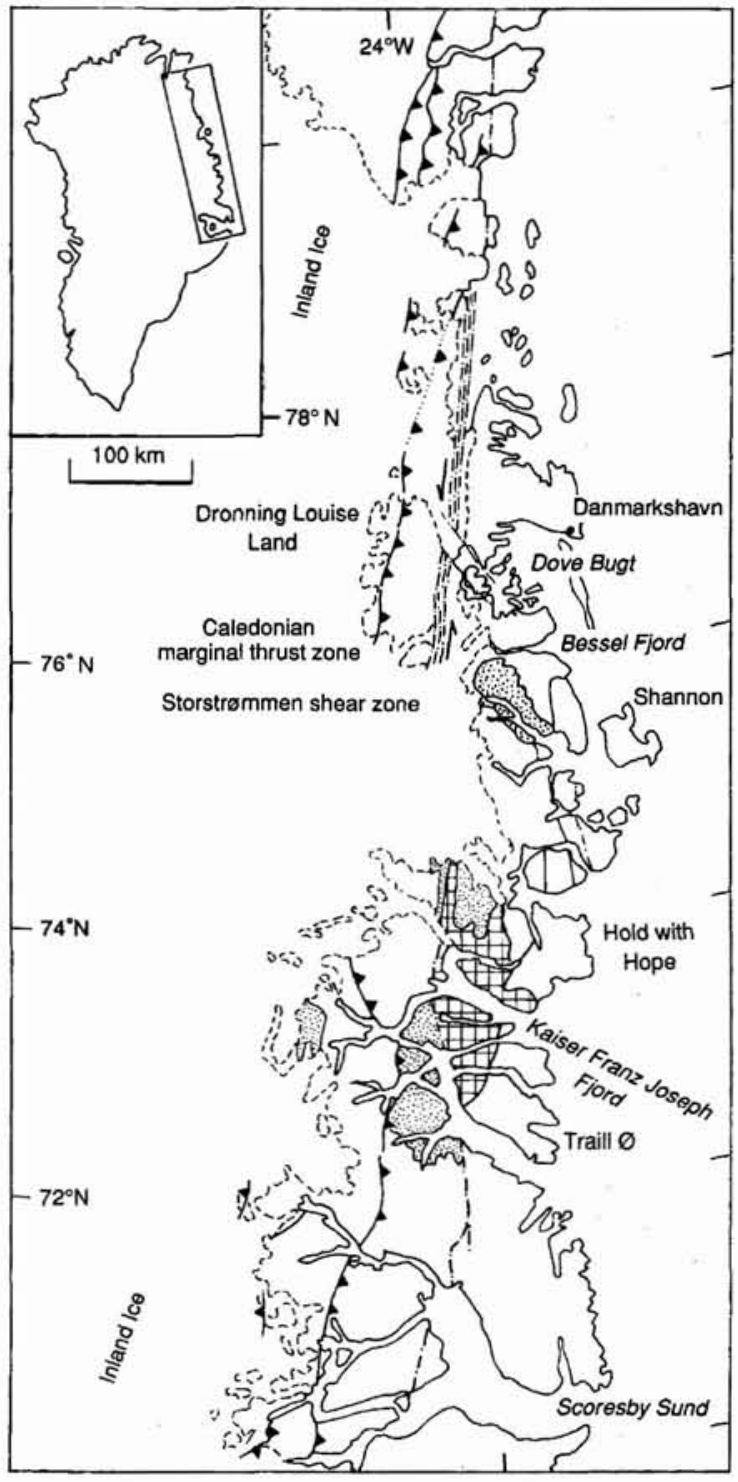

Fig. 1. Sketch map of East Greenland showing the position of Dove Bugt in relation to the margin of the Caledonian orogenic belt and the Storstrømmen shear zone. Eleonore Bay Supergroup = stippled; Devonian outcrops (from Larsen \& Bengaard, 1991) $=$ cross-hatched.

gneisses (Fig. 2). A complex series of gneiss-forming events and injections of mafic sheets (now amphibolites) preceded emplacement of the sheets of pink granite, but their petrogenesis and tectonic significance are unknown. Mafic dykes were also emplaced after the pink granites but before the nappe-forming events.

The nappe-forming events were associated with mylonitisation that was concentrated in relatively thin, gently dipping shear zones which are broadly concordant with foliation in the gneisses and supracrustal rocks.
Shear criteria indicate a consistent shallow, NE-directed displacement. The nappes and mylonites are deformed by upright to inclined folds that are associated with lowangle shear zones dipping south-east.

The distribution of the various orthogneisses and variations in the structural complexity led Chadwick \& Friend (1991) to interpret the regional structure in western Dove Bugt in terms of three tectonic units (A, B, C; Fig. 2) juxtaposed along low-angle mylonites. The juxtaposition is presumed to have taken place late in the tectonic history because of the variations in lithology and structures in each of the tectonic units.

Because of the complexity of the regional structure and the large areas of fjord it is not possible to present a complete map. Instead the structure is illustrated in the form of detailed maps of selected areas. These maps are drawn from three main areas which are separated by two steep, NW trending, brittle faults (Chadwick \& Friend, 1991). Part of one of these faults, the Bagfjord fault, is exposed in the south of Lindhard $\varnothing$, but the other fault, which is inferred to lie between Lindhard $\varnothing$ and Daniel Bruun Land, is concealed by the waters of Borgfjorden (Fig. 2).

This paper amplifies data already reported in outline (Chadwick \& Friend, 1991) and it places the structures in the western part of Dove Bugt in the more general context of basement reactivation under high-grade ductile conditions. Further, the evidence for the timing of deformation and, in particular, the extent to which the structures can be regarded as Caledonian in age are reviewed. Common, late-stage, ductile and brittle extensional structures in western Dove Bugt are believed to have resulted from orogen-parallel collapse of the Caledonian belt of NorthEast Greenland. Finally, a post-Caledonian fracture system, which may be related to Palaeozoic and Mesozoic basin development and Early Tertiary sea-floor spreading in the Norwegian-Greenland Sea region, is described.

\section{Tectonic fabrics}

Fabrics in the gneisses and supracrustal rocks in western Dove Bugt are commonly composite, comprising several distinct components which were the result of polyphase deformation. Older linear (L) and planar (S) fabrics were reoriented and reinforced during periods of deformation which gave rise to the nappes, mylonites, north-westerly verging folds and the late-stage extensional structures. Other $\mathrm{L}$ and $\mathrm{S}$ fabrics are solely the result of these later periods of deformation. Some of the older fabrics are probably related to Early Proterozoic gneiss-forming events which occurred prior to the emplacement of the sheets of pink granites.

Many of the folds that are related to the periods of 
deformation younger than the sheets of pink granites have $\mathrm{S}$ fabrics which formed as a result of new mineral growth that was superimposed on folded gneissic foliations and mylonite fabrics. On the other hand, many of the fabrics in the folds and mylonites that are younger than the Early Proterozoic granites are composite in the sense that they

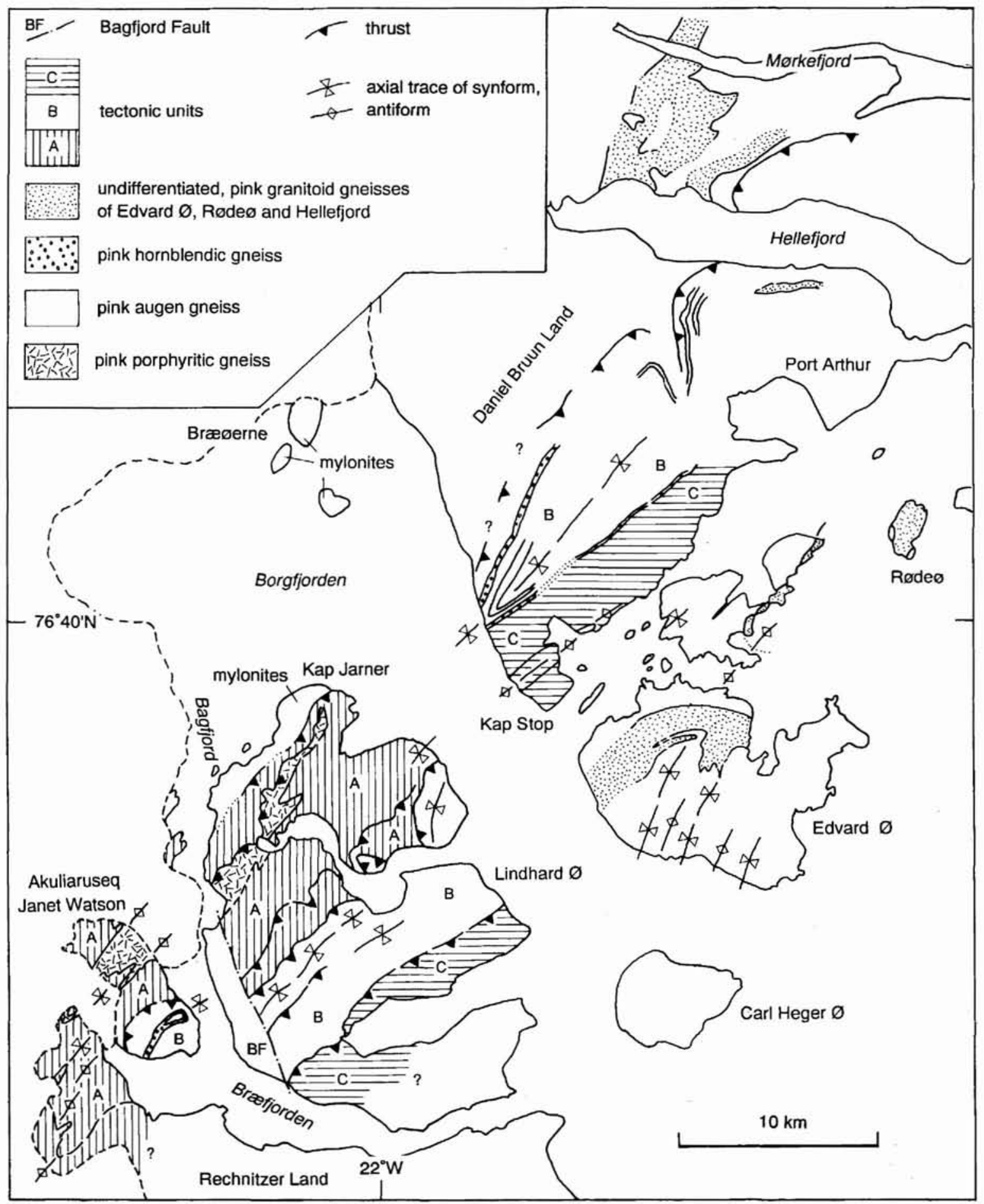

Fig. 2. Sketch map of the western part of Dove Bugt showing the tectonic units A, B and C with their bounding thrusts. The principal outcrops of the different Early Proterozoic granitic rocks used to distinguish the units are indicated. 

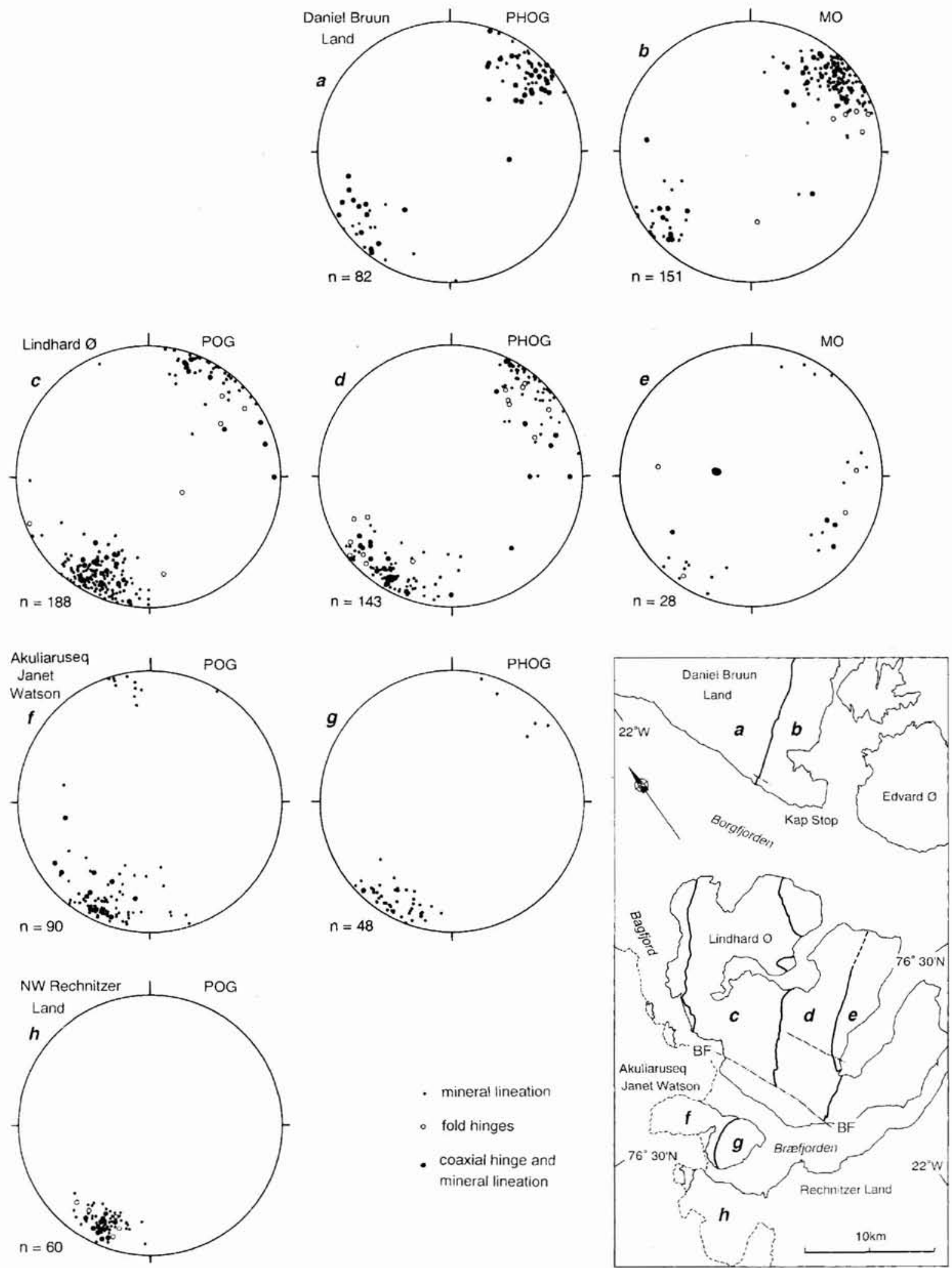

- mineral lineation

- fold hinges

- coaxial hinge and mineral lineation

Fig. 3. Equal area stereographic projections for linear data from sub-areas of Dove Bugt. The sub-areas are geographically and structurally arranged (see inset) and are designated according to the type of granitoids found within them: POG = porphyritic orthogneiss; PHOG = porphyritic hornblende orthogneiss; $\mathrm{MO}=$ mixed orthogneiss. 
are related to earlier fabrics which were reinforced during later deformation. This composite relationship adds to the difficulty of determining whether the ductile structures in western Dove Bugt are Caledonian or older.

Mélanges comprising coarse fragments of marble and gneiss in a matrix of marble are relatively common within low-angle shear zones associated with nappe emplacement and younger deformation. These mélanges have undergone extensive late- or post-tectonic recrystallisa-

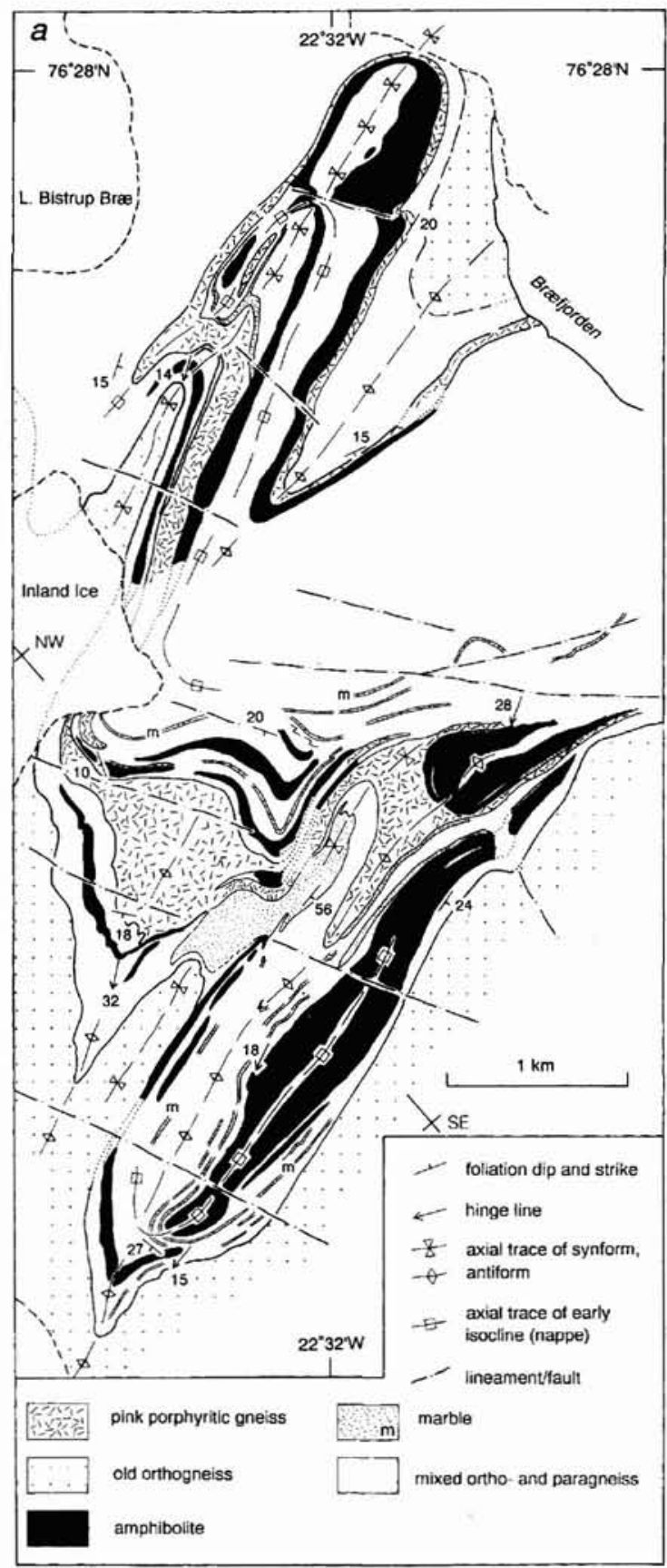

tion which gave rise to coarse granoblastic-polygonal textures in the carbonate matrix. Pre-existing intense mylonite fabrics, which indicate the high strains that were accommodated before the recrystallisation, are frequently preserved in boudinaged quartzo-feldspathic sheets within the mélanges. The annealing of the carbonate matrix shows that thermal effects outlasted deformation, with $T$ exceeding the annealing temperatures of calcite ( $c$. $300^{\circ} \mathrm{C}$; Schmid et al. 1980) but not of quartz $\left(c .450^{\circ} \mathrm{C}\right)$.

A prominent linear fabric which comprises a variably intense, preferred parallel orientation of minerals such as amphiboles and micas and the elongation of mineral aggregates is found throughout western Dove Bugt (Fig. 3 ). This lineation is commonly coaxial with various generations of folds that are younger than the sheets of Early Proterozoic granites. This coaxial relation with different generations of folds appears to be the result of a combination of effects. These include: (1) rotation of the axes of older folds (in particular those related to the two principal periods of nappe formation) into parallelism with the axes of younger folds; and (2) superimposition of younger folds, with north-westerly vergence, onto older folds (whose axes already had a shallow plunge to the north-east or south-west because they are part of the large-scale sheath form of the principal nappes in the western part of Dove Bugt). The orientation of the L fabric is summarised (Fig. 3) in terms of a series of sub-areas which were defined with regard to significant regional variations in the orientation of mineral lineations and fold axes. These variations relate in part to their position within the three different tectonic units $\mathrm{A}, \mathrm{B}$ and C (Fig. 2). Late or post-tectonic recrystallisation has blurred the linear fabric in some outcrops in the same way that late annealing has locally obscured $\mathrm{S}$ fabrics in some of the mélanges.

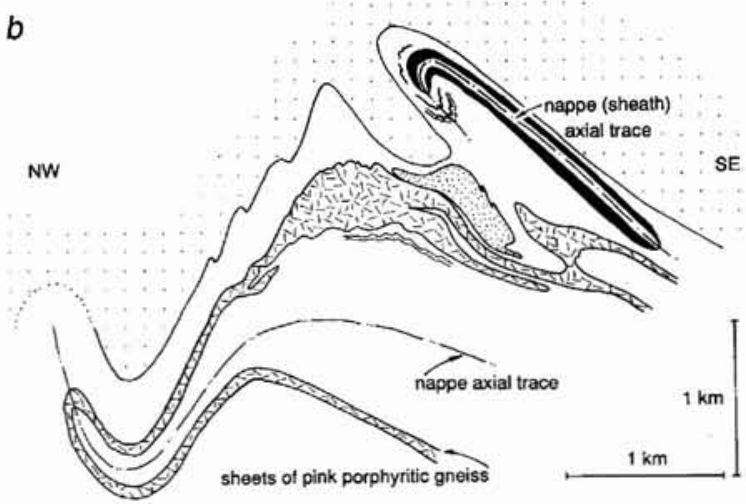

Fig. 4. (a) Detail of the geology of a part of north-western Rechnitzer Land (see Fig. 2). (b) Approximate true-scale cross section along the line NW-SE illustrating the form of the NW verging folds and the early sheath structures. 


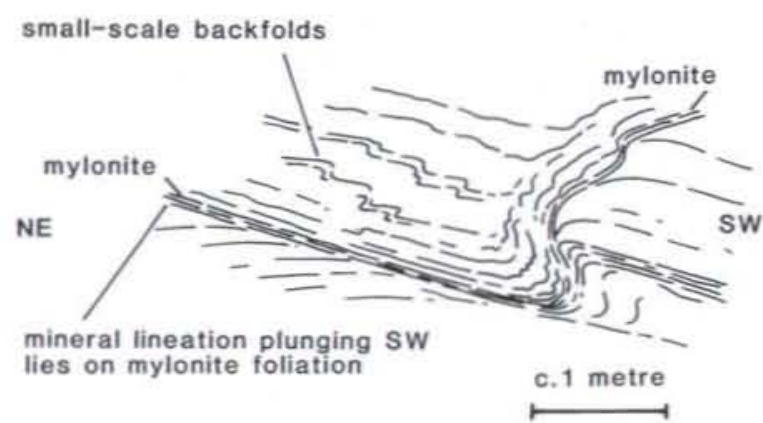

Fig. 5. Sketch of outcrop showing contractional structures in mixed gneisses in north-west Rechnitzer Land.

\section{North-west Rechnitzer Land and Akuliaruseq Janet Watson}

This area includes two parts of the lower tectonic units (A and B; Fig. 2). Unit A is characterised by sheets of porphyritic pink orthogneiss (POG; Chadwick \& Friend, 1991) which were emplaced into an intersheeted complex of supracrustal gneisses and amphibolites and migmatitic orthogneisses (old orthogneiss, Fig. 4a). The higher tectonic unit, B, contains sheets of pink homblendic orthogneiss (PHOG; Chadwick \& Friend, 1991) which were emplaced principally into mixed para- and orthogneisses. These units are separated by a zone of mylonites and ultramylonites which is interpreted as a thrust because the mylonitic rocks separate lithologically distinct packages (Fig. 2). We regard the thrust as a late structure that developed during the period of north-westerly verging folds. These folds and their associated thrusts are presumed to have been generated as a result of shortening with low-angle displacements up from the south-east. There are no unambiguous linear fabrics plunging southeast on the thrusts to confirm the displacement direction. It is conceivable that the late thrusts and north-westerly verging folds may be lateral ramp phenomena associated with north-easterly displacements that continued after the generation of the late nappes.

The structure of tectonic unit A in north-west Rechnitzer Land is marked by a prominent interference pattern which resulted from the refolding of early nappes by upright to inclined folds in a multilayer system of intersheeted amphibolites, marble, mixed para- and orthogneisses and a major sheet of pink porphyritic gneiss (Fig. 4a, b). The form of one of the nappe closures in the large body of amphibolite in the south-east of the interference pattern suggests that it has a sheath structure.

The shear sense indicated by porphyroclasts of feldspar and contractional structures in the mylonites (Fig. 5), in the orthogneisses and the sheet of pink porphyritic gneiss in the lower limb of the larger nappe (Fig. 4b) shows that the nappe transport was towards the northeast. Lenses of anatectic melt (Fig. 6) which are coplanar with the axial surfaces of small-scale parasitic folds in the core of the later antiform that deforms the upper limb of this nappe (Fig. 4b) show that high temperature conditions that prevailed during the emplacement of the nappes also occurred during the younger period of folding.

Tectonic unit A can be traced north-eastwards onto north-western Akuliaruseq Janet Watson (Fig. 2) where a major antiform defined by pink porphyritic orthogneiss dominates the structure. The axial surface of this antiform dips gently south-east and its axis plunges gently southwest. This fold is part of a regional system of asymmetric,

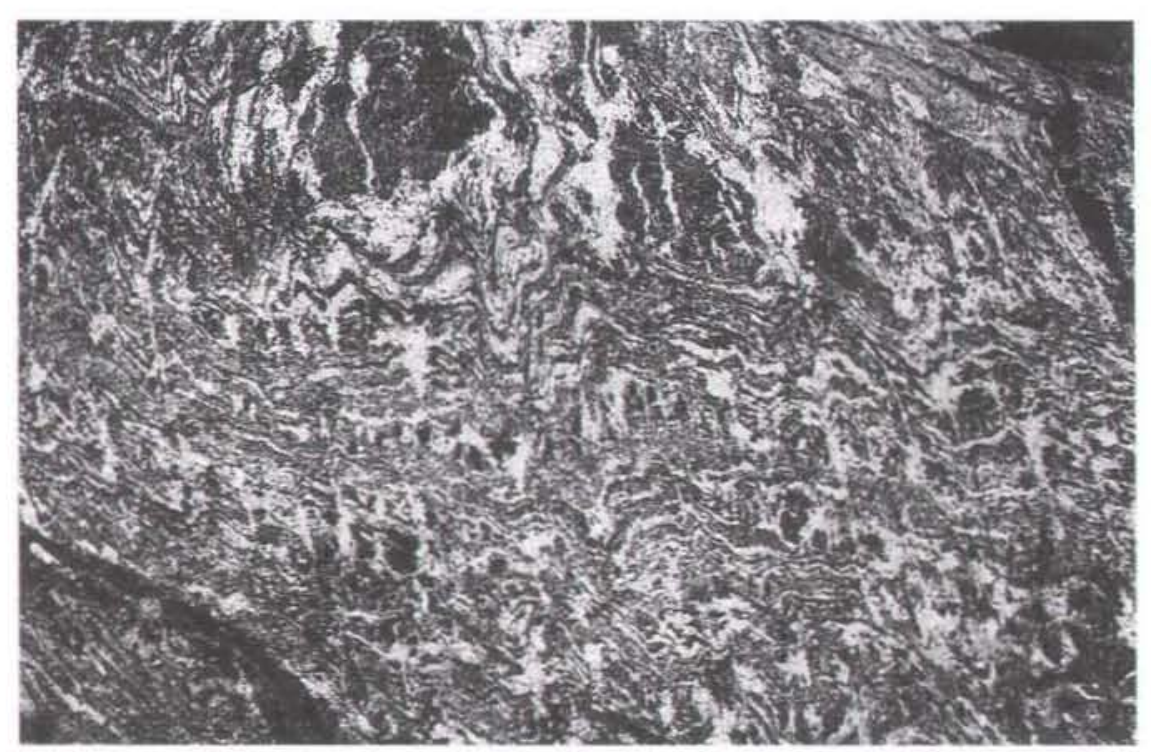

Fig. 6. Lenses of anatectic melt parallel to steep axial surfaces of small-scale folds parasitic on the large upright folds that deform the nappes in north-west Rechnitzer Land. 
Fig. 7. Sketch (from a photograph) of cliffs at the north-eastern end of Akuliaruseq Janet Watson showing early nappe trace refolded by a subhorizontal nappe with later thrusts refolded by upright synform. Ornaments: ruled $=$ basic gneisses; dots $=$ sheets of porphyritic hornblende orthogneiss.

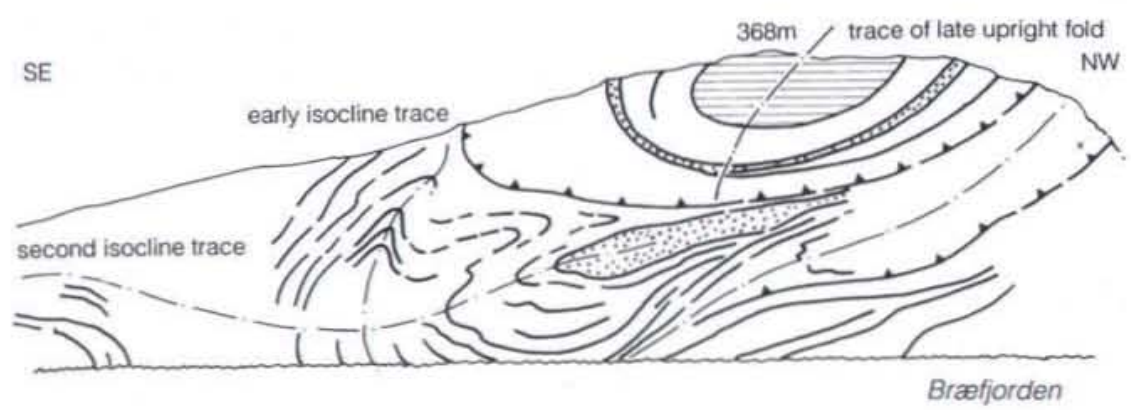

c. $100 \mathrm{~m}$
NW verging folds in unit $A$ in north-west Rechnitzer Land and Akuliaruseq Janet Watson which deform earlier isoclines (Chadwick \& Friend, 1991).

The south-eastern part of Akuliaruseq Janet Watson lies within the higher tectonic unit B (Fig. 2) which is characterised by sheets of pink hornblendic orthogneiss. The structure is well-displayed on the north-east side of the peninsula in a cliff section c. $400 \mathrm{~m}$ high (Fig. 7) which shows early isoclines deformed by later isoclines. Both sets of isoclines are folded by an upright synform. Major décollements marked by mylonites and ultramylonites up to a few metres thick in the gentle slopes southwest of the cliff section are folded by a large isocline which appears to be part of the second set. This relationship is in accord with evidence from elsewhere in western Dove Bugt which shows that mylonites formed as part of the nappe system prior to younger upright folding. In spite of the effects of folding by the large isocline, extensional structures (Fig. 8), including shear bands, and asymmetric augen structures of feldspar porphyroclasts in the mylonites in the lower limb of the isocline show that displacements were from south-west to north-east like those in north-west Rechnitzer Land. The thrust which separates the tectonic units A and B (Fig. 2) in south-east Akuliaruseq Janet Watson is inferred from differences in the lithological associations in each unit and by extrapolation from an exposed thrust boundary between the same tectonic units on Lindhard $\emptyset$.

Linear fabrics in both tectonic units are defined by amphiboles and elongated grains or aggregates of quartz and feldspar. In north-west Rechnitzer Land, the L fabric displays a relatively simple, tightly clustered grouping plunging gently south-west coaxial with fold hinge lines (Fig. 3h). On Akuliaruseq Janet Watson, the L fabric has a more variable orientation (Fig. 3f,g) with distinct groups plunging north-north-west, north-east and southwest. The group plunging north-north-west appears to be related to deformation earlier than the upright to inclined
Fig. 8. Photograph of extensional structures in orthogneisses from the northern side of Akuliaruseq Janet Watson. North is to the left. south to the right of the photograph, lens cap $55 \mathrm{~mm}$ (width of field of view $1.6 \mathrm{~m}$ ).

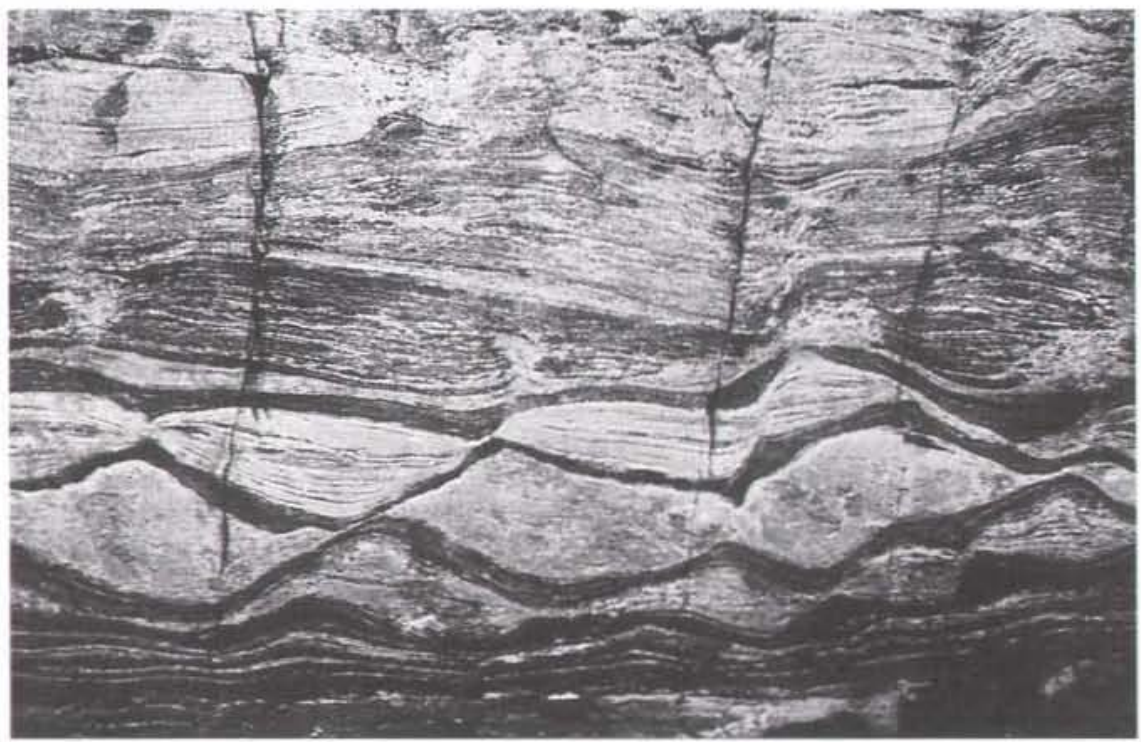




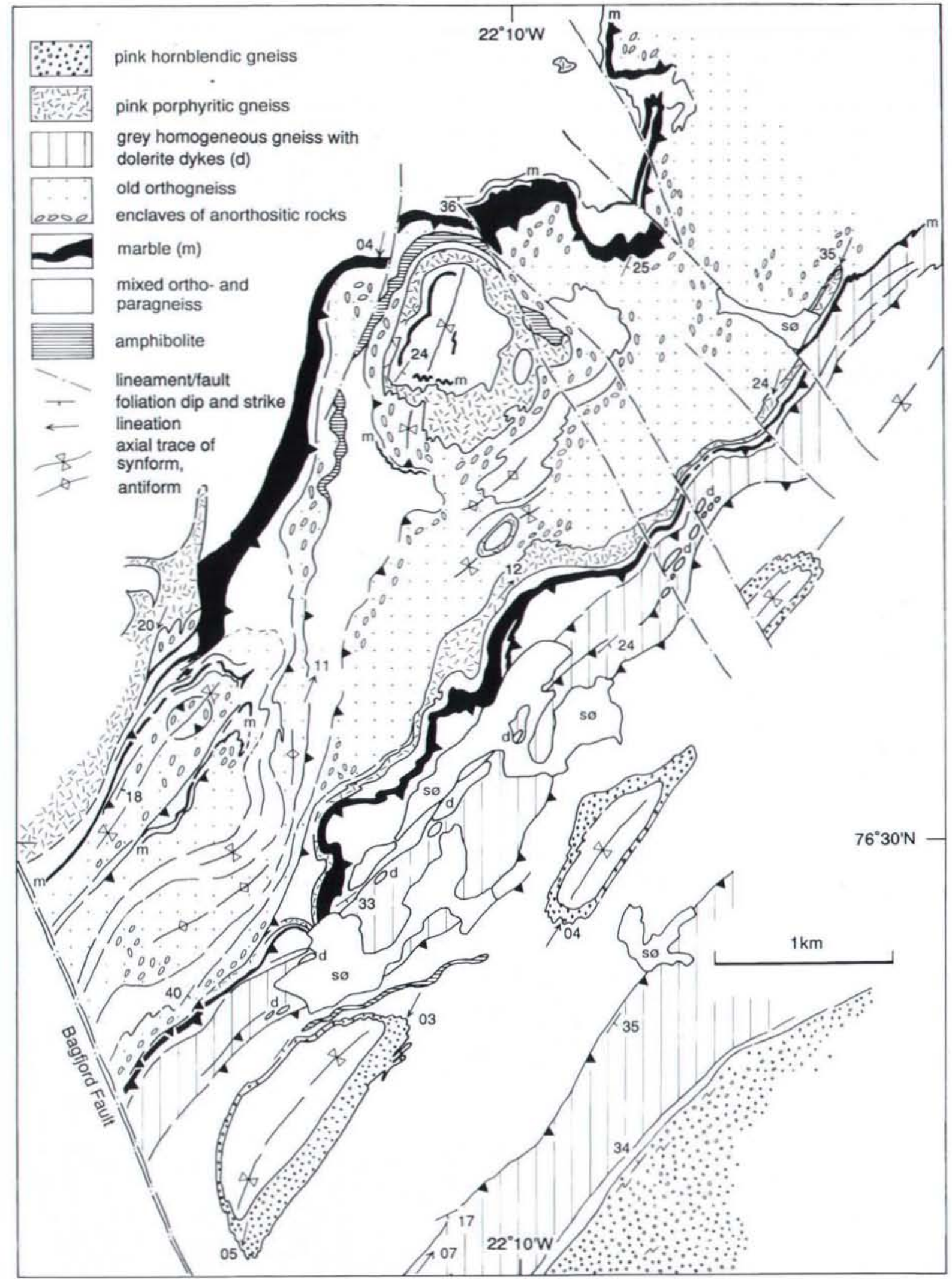

Fig. 9. Detail of the geology of central Lindhard $\emptyset$, north-east of the Bagfjord Fault across the three tectonic units A, B and C (see Fig. 2 for location). 
folds on the grounds that some outcrops include refolded lineations. The nappes and younger upright to inclined folds are broadly coaxial with the L fabric in this peninsula, but in some outcrops the lineation is slightly oblique to the fold hinge lines. This relationship suggests that part of the $\mathrm{L}$ fabric was probably related to the earlier nappes and was rotated during the younger folding.

\section{Lindhard $\emptyset$}

This island provides the most complete cross-section of the structure that was mapped in western Dove Bugt and it includes parts of each of the three tectonic units A, B and C (Fig. 2). South-west of Kap Jarner, the northwestern margin of the island is made up entirely of thick $(>200 \mathrm{~m}$ ) mylonites and ultramylonites which dip gently to the south-east. They appear to have been derived largely from pink porphyritic orthogneisses comparable with the pink orthogneisses in unit A, although paragneisses, amphibolites and marble were also involved. S-C fabrics, textures of feldspar porphyroclasts and contractional structures in these mylonites indicate that the principal displacement was subhorizontal and towards the north-east. Similar thick mylonites, also involving paragneisses and marbles, are found on the Breøerne (Fig. 2). These mylonites are presumed to form the eastern margin of the Storstrommen shear zone, displaced by some $5 \mathrm{~km}$ to the south-east by the Bagfjord and Borgfjorden faults (Figs 1, 2).

The mylonites are overlain by mylonitised grey orthogneisses which are intersheeted with forsterite-norbergite-diopside marble and mélanges of marble with blocks of grey orthogneiss and quartz-rich paragneiss. This in- tersheeted complex is regarded as the base of tectonic unit A. The intercalation of large sheets or lenses of orthogneiss with marble mélanges suggests that the complex is an imbricate zone. Shear sense phenomena in the mylonitised orthogneisses also indicate transport towards the north-east. The intersheeted marbles and gneisses are deformed by large north-westerly verging folds with shallow plunge to the south-west coaxial with the linear fabric in the mylonites. These folds drop the structure progressively down to the north-west. Coarse granoblastic-polygonal textures of calcite in the marbles indicate that significant thermal effects outlasted the deformation.

The intersheeted marbles and grey orthogneisses are overlain by a sheet of pink porphyritic orthogneiss with a mylonitised base (Fig. 2) dipping gently south-east. Shear sense indicators in the basal mylonites suggest a southwest to north-east displacement. The basal contact can be traced south-west from above Kap Jarner to just north of the Bagfjord fault. We regard this as a thrust within tectonic unit A. Immediately south of Kap Jarner, the sheet of pink porphyritic orthogneiss appears to form the core of a major isocline, but details of the structure are uncertain. The thrust at the base of the sheet is extensively reddened and epidotised as a result of later, relatively brittle reactivation. This reactivation may be related to late- or post-orogenic collapse on the grounds of similar effects on thrusts in Daniel Bruun Land and the ground north of Hellefjord, which are described later.

This sheet of pink orthogneiss is overlain by mixed para- and orthogneisses and other thinner sheets of pink orthogneiss. The top of tectonic unit A on Lindhard $\emptyset$ (Figs 2,9 ) is marked by a complex thrust interdigitation of pink porphyritic orthogneiss, marble (including mé-
Fig. 10. Deformed enclave of gabbro-anorthosite in mylonitised orthogneiss within a thrust zone, Lindhard $\emptyset$.

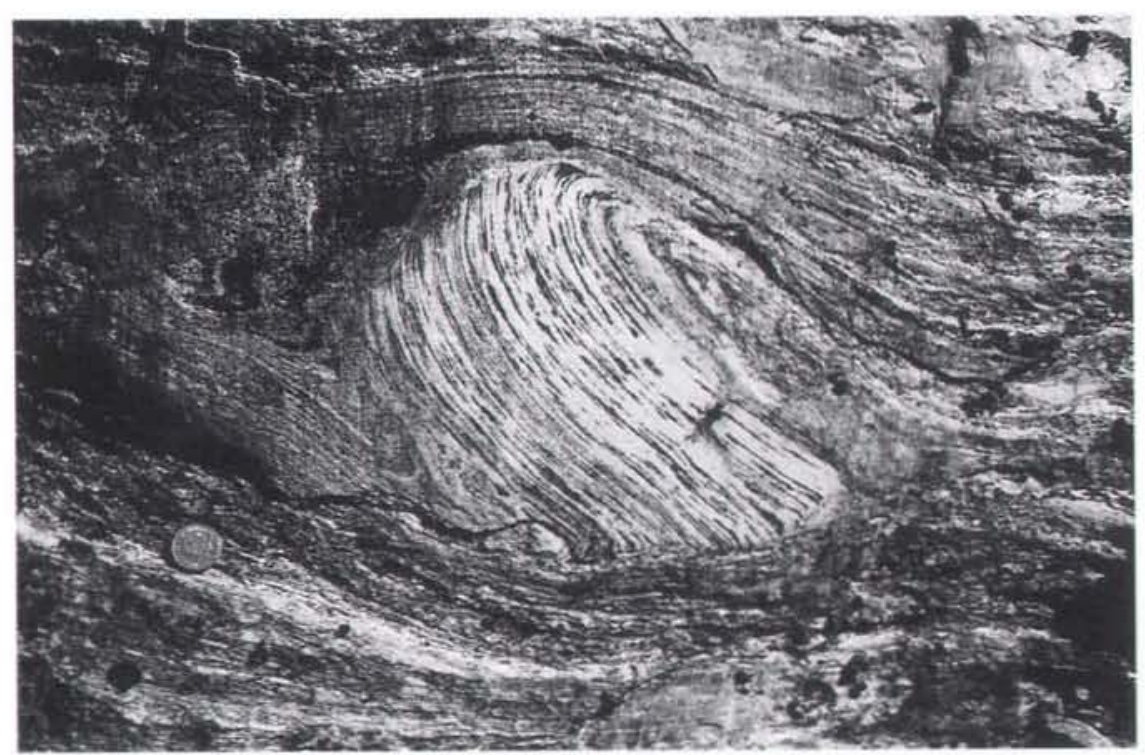




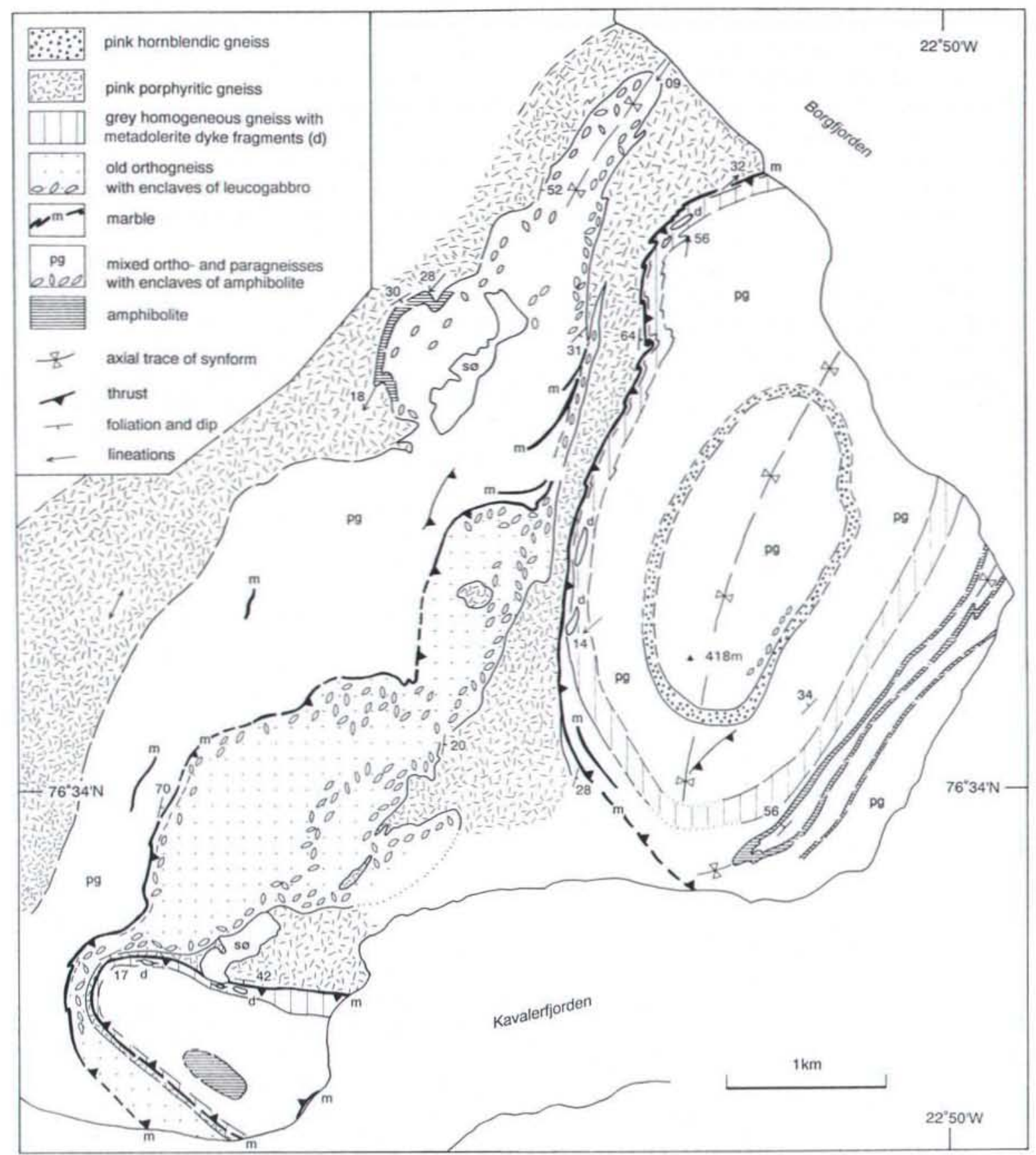

Fig. 11. Detail of the geology of the north-eastern part of Lindhard $\emptyset$ across tectonic units A and B (see Fig. 2 for location).

langes), old orthogneiss with enclaves of gabbro-anorthosite and mixed para- and orthogneisses. Some of the enclaves of gabbro-anorthosite have been deformed within the thrust zones (Fig. 10). The thrusts dip gently south-east and linear fabrics plunge gently north-east or south-west (Fig. 3c, d, e). An imbricate stack with associated folds appears to dominate the structure at the top of unit A immediately north of the Bagfjord fault (Fig. 9).

Tectonic unit B in the central part of Lindhard $\emptyset$ (Figs $2,9)$, is characterised by concordant sheets of pink hornblendic orthogneiss and grey homogeneous orthogneiss with large boudins of metadolerite derived from attenuated dykes (Figs 9,11) hosted by mixed para- and orthogneisses. The base of unit B is defined by a thrust within 
a marble unit just below the sheet of grey homogeneous orthogneiss (Figs 9, 11). Small-scale structures including folds, deformed ramps and extensional shear bands (Fig. 12) indicate displacement towards the north-east in the mylonites adjacent to the contact between units $\mathrm{A}$ and $\mathrm{B}$. Thrusts marked by mylonites also occur within unit B. The unit is in the form of a large synform (Fig. 9) which can be correlated with the regional late-stage folds with north-westerly vergence. The synform and its associated parasitic folds are coaxial with the shallow regional linear fabric (Fig. 3).

Tectonic unit $\mathrm{C}$ overlies unit B in south-east Lindhard $\emptyset$ (Figs 2, 9). Mylonites within its contact with unit B also display structures which indicate relative displacement of unit $\mathrm{C}$ to the north-east. Unit $\mathrm{C}$ is characterised
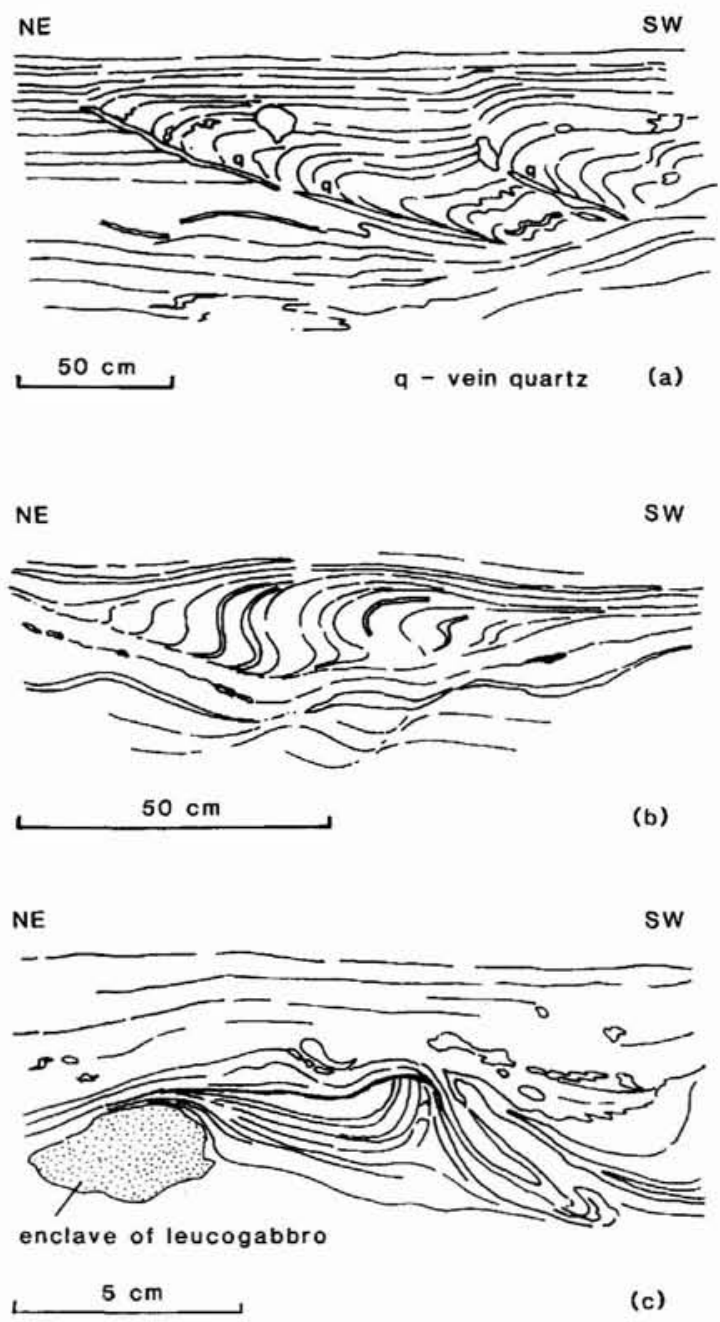

Fig. 12. Sketches from photographs of small-scale structures associated with top-to-the-north-east displacements in mylonitised orthogneisses in thrusts, Lindhard $\emptyset$. by mixed orthogneisses which are made up of two distinct facies. The older is a grey, homogeneous, biotite gneiss with variable amounts of pegmatite layering. The younger facies is a pink, inhomogeneous, granitic gneiss commonly with a schlieric aspect which is the result of an intimate association of grey gneiss and coarser pink pegmatitic gneiss. Little is known of the structure of unit C and its top has not been defined. Fabrics in this unit have trends which are closely comparable with those in other units in Lindhard $\varnothing$ (Fig. 3).

Linear fabrics have orientations in common with those in north-west Rechnitzer Land and Akuliaruseq Janet Watson (compare Fig. 3c, f, h). However, there are significant differences in the east of Lindhard $\varnothing$ where the L fabric has a more dispersed pattern (Fig. 3e). The variations in the orientation of the $\mathrm{L}$ fabric on Lindhard $\varnothing$ show that whereas there are similarities in the patterns in tectonic units $\mathrm{A}$ and $\mathrm{B}$, unit $\mathrm{B}$ has more northerly plunging structures. The difference is related to the presence in unit B of more non-cylindrical folds than in unit A, some of which have an extreme sheath-like morphology. The highest tectonic unit, $\mathrm{C}$, has a much greater variation of $\mathrm{L}$ fabric orientations (Fig. 3e). These differences in L fabric orientation in units $\mathrm{A}, \mathrm{B}$ and $\mathrm{C}$ are interpreted in terms of a greater degree of preservation of older structures in the highest unit, $\mathrm{C}$, compared with the underlying units $\mathrm{A}$ and $\mathrm{B}$, which implies a greater intensity of deformation related to overthrusting from south-west to north-east in the lower units.

\section{Daniel Bruun Land}

The structure in this part of western Dove Bugt is known in detail only in an area extending for a few kilometres north of Kap Stop (Figs 2, 13). Tectonic unit C (Fig. 2) has been recognised on the grounds of the occurrence of mixed orthogneisses like those found in unit $C$ on Lindhard $\varnothing$. The boundary between units $C$ and $B$ is taken to be the zone of thin impersistent mylonites and marble 1-2 m thick on the east side of the pink hornblendic orthogneiss in the steep eastern limb of the large synform north-west of Kap Stop (Fig. 2). This boundary zone is presumed to represent a thrust which may become shallow at depth to the south-east. Sheets of pink augen orthogneiss occur within the core of the synform, but sheets of similar gneiss also occur in unit $\mathrm{C}$ to the southeast (Fig. 13). It is conceivable that the main sheet of pink augen orthogneiss in the core of the synform links with those south-east of the pink hornblendic orthogneiss, but no cross-cutting relationships between the sheets of pink orthogneisses were found. In the absence of this evidence, tectonic unit $\mathrm{C}$ is regarded as distinct from unit $\mathrm{B}$ which occupies the core of the synform and includes the 


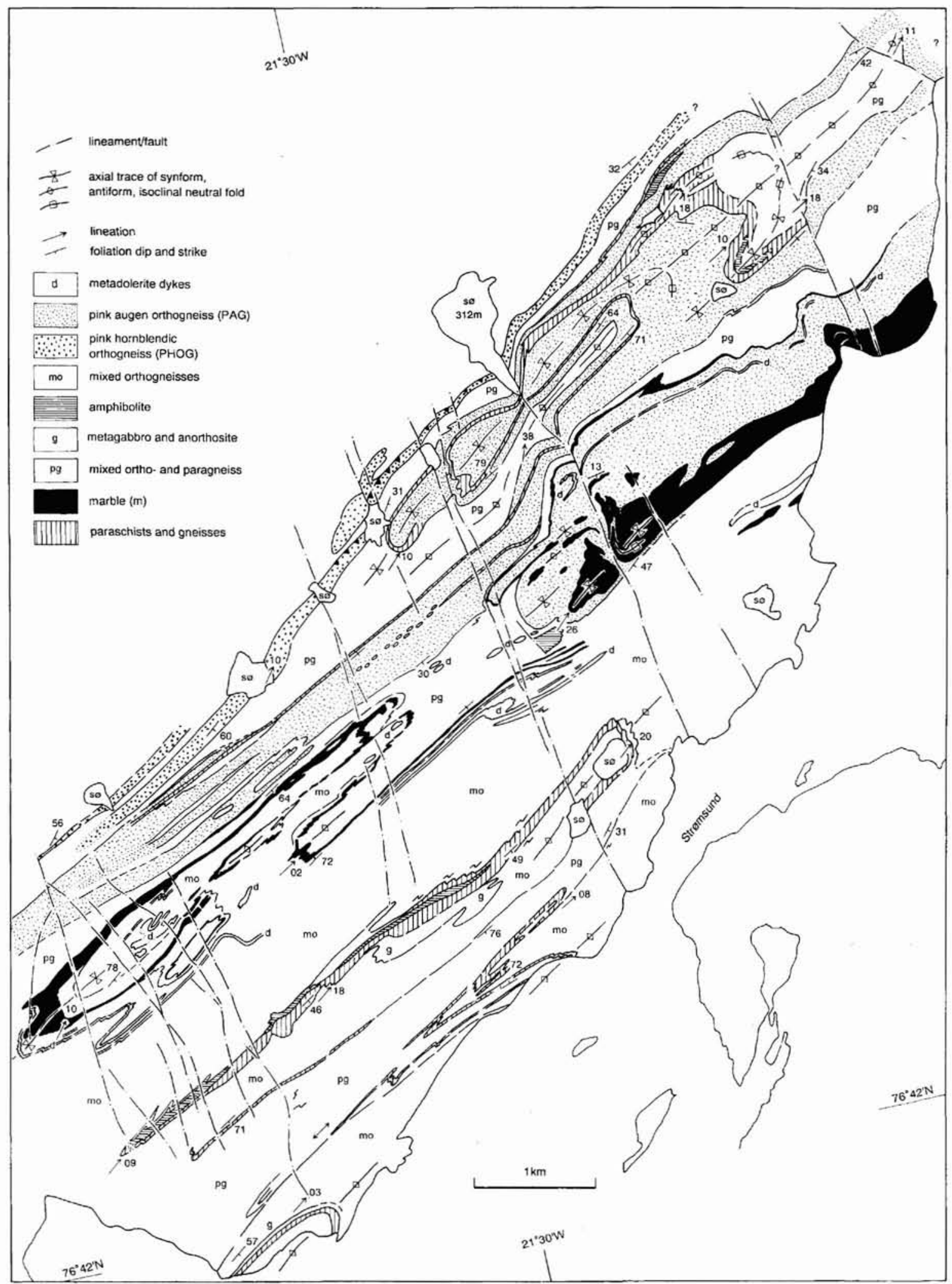

Fig. 13. Detail of the geology of tectonic units B and C in the area immediately north of Kap Stop, Daniel Bruun Land (see Fig. 2 for location). 
peripheral sheet of pink hornblendic orthogneiss at its base.

The bulk of unit B, the internal structure of which was not mapped in detail, comprises metasedimentary gneisses, schists and amphibolites with subordinate marble. A series of mylonites dip gently south-east below the sheet of pink hornblendic orthogneiss (Fig. 2) on the western limb of the synform. Many of these mylonites are manifested as thin zones at the base of sheets of pink orthogneisses which extend south-west from Hellefjord (Fig. 2). They have compressional kinematic indicators and are, therefore, interpreted as thrusts. Intensely deformed, intersheeted marble and grey orthogneisses lie beneath these thrusts further north-west in Daniel Bruun Land.

Tectonic unit $\mathrm{C}$ comprises a wide range of supracrustal rocks, including abundant marble, and mixed gneisses intersheeted with pink augen orthogneisses, mixed orthogneisses and older orthogneisses. The structure of unit C in the area of Kap Stop is dominated by a major antiform which is outlined by a sheet of layered gabbro-anorthosite and metasedimentary gneisses and schists. The axial surface dips steeply south-east and the fold plunges gently north-east. Its hinge is exposed across the bay north of Kap Stop (Fig. 2). The antiform in this part of Daniel Bruun Land appears to be part of a system of late folds, including the major synform to the north-west, which trends north-east and verges north-west. They may be correlated with similar late folds in Lindhard $\emptyset$, Akuliaruseq Janet Watson and north-west Rechnitzer Land.

In Daniel Bruun Land these late folds plunge gently north-east or south-west and they are coaxial with the regional mineral lineation (Fig. 3a,b). The late folds deform large isoclines with the dimensions of nappes (limb lengths $>5 \mathrm{~km}$ ) which in turn deform earlier largescale isoclines resulting in complex interference patterns between these three sets of folds (Fig. 13). The earliest isocline passes south from a large hinge area which is

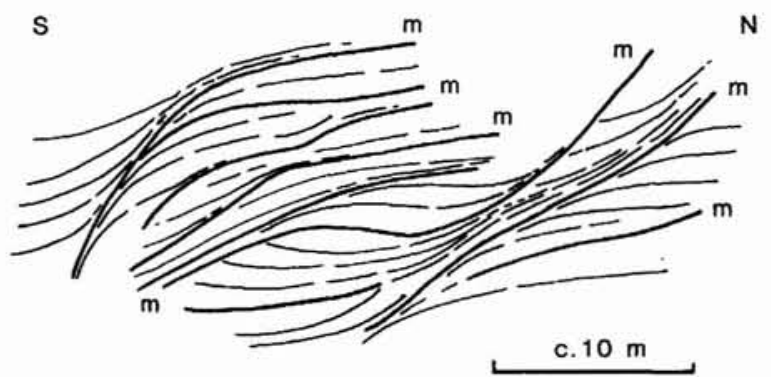

$m$ - thin seam of mylonite with friction polish and down-dip slickencrysts

Fig. 14. Sketch from photograph of late extensional structures in orthogneisses, Daniel Bruun Land. occupied by mixed para- and orthogneisses and amphibolites surrounded by pink augen orthogneisses into an intensely attenuated core which is represented solely by a few metres of paraschist (Fig. 13). This core can be traced for at least $12 \mathrm{~km}$ around the younger isocline and beyond to the south-west. A relatively persistent sheet of marble defines another complex pattern of interference between an isocline and younger, broadly coaxial, folds (Fig. 13). Large- and small-scale closures in the intersheeted marble and mixed orthogneisses have the form of sheath folds. These interference patterns show that the folding in Daniel Bruun Land was characterised by extreme attenuation of all the older and younger folds. This attenuation lasted into the latest stage of NW verging folding when earlier mineral lineations were rotated into parallelism with the hinges of the late folds. These extremely ductile effects occurred under amphibolite facies conditions which are indicated by a complex sequence of anatectic segregations in the pink augen orthogneisses.

The thrusts which extend north-east from Daniel Bruun Land across Hellefjord (Fig. 2) were reactivated by relatively brittle movements. The thrusts are reddened, epidotised and locally enriched in carbonate in vein systems. Conjugate shear zones immediately above one thrust south of Hellefjord indicate that extensional displacements to the south-west and north-east occurred during the reactivation. These displacements can be correlated with numerous, broadly east-west, steeply dipping, small-scale extensional shear zones dropping to the south in the gneisses in many parts of Daniel Bruun Land (Fig. 14). Other extensional structures are abundant in the gabbro-anorthosite at Kap Stop. They include listric faults and complex systems of conjugate fractures (Fig. 15) which indicate transitional ductile to brittle strains. All of these structures post-date the youngest folds and they lie approximately perpendicular to the trend of the Caledonian orogenic belt in North-East Greenland.

\section{Kinematics of the deformation in the high- grade gneiss terrain in western Dove Bugt}

The intersheeted complex of grey orthogneisses and supracrustal amphibolites, schists and marbles had already undergone significant pervasive ductile deformation and migmatisation prior to the emplacement of pink granitic orthogneisses, now known to include a group emplaced at $c .1740 \mathrm{Ma}$ (Kalsbeek et al., 1993). Therefore, the tectono-metamorphic events that preceded the emplacement of these granitic sheets were at least Early Proterozoic in age. However, no unambiguous, largescale structures related to these events have been recognised. Deformed amphibolite dykes within the grey homogeneous orthogneisses and the sheets of pink gran- 

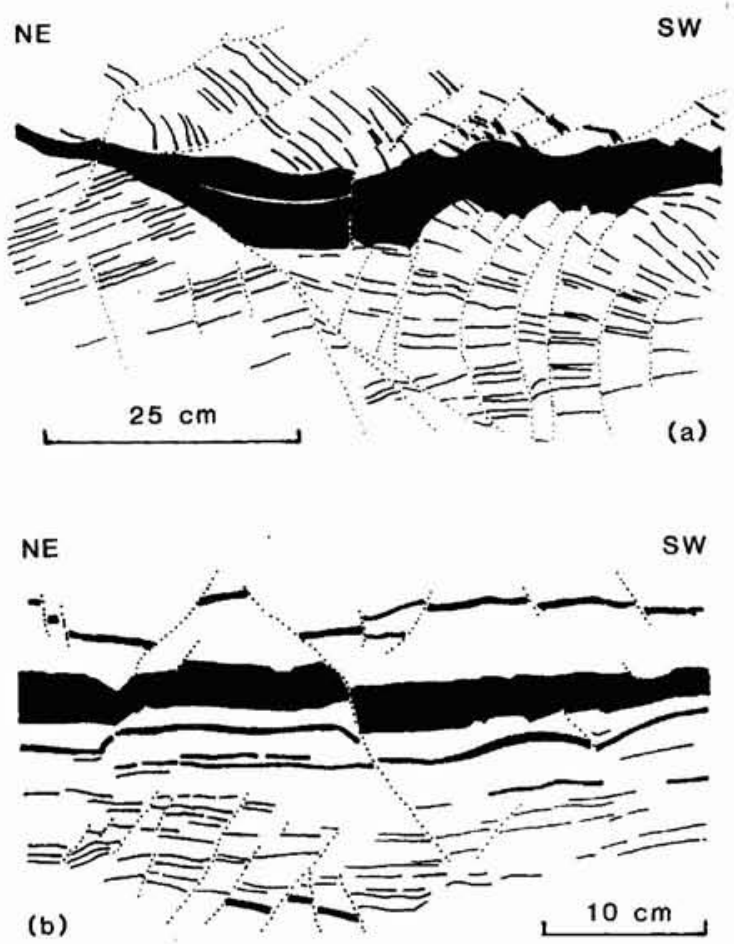

NE
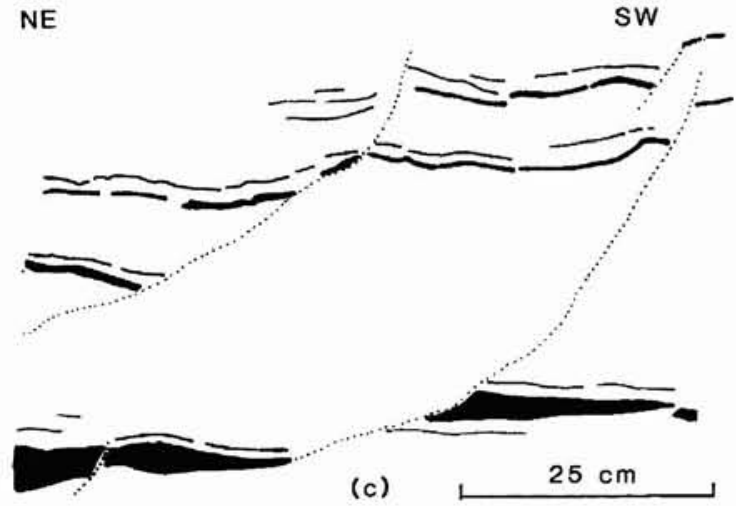

Fig. 15. Sketches from photographs of late, brittle extensional structures in gabbro-anorthosites, Kap Stop. Black layers represent hornblendite/melagabbro layers; leucogabbro and anorthosite are unornamented.

itic orthogneisses have low-angle discordances with the foliation in their host (Chadwick \& Friend, 1991). Whereas many of these dykes may be younger than $c$. $1740 \mathrm{Ma}$, we have no evidence to suggest that they mark any significant period in the tectonic chronology. Strachan et al. (1992) reported variably deformed and metamorphosed dolerite dykes in the basement gneisses and Proterozoic sedimentary rocks in Dronning Louise Land which they correlated with dolerites in North Greenland that have yielded $\mathrm{Rb}-\mathrm{Sr}$ whole rock ages of $c .1250 \mathrm{Ma}$. It is conceivable that the mafic dykes in eastern Dronning Louise Land and western Dove Bugt are of comparable age, but no firm correlations can be made. The complex record of Early Proterozoic deformation, metamorphism and emplacement of granite sheets and Proterozoic mafic dykes thus remains far from clear.

Deformation younger than the persistent Early Proterozoic granite sheets in western Dove Bugt was superimposed on a complex high-grade gneiss terrain with a layer-cake structure. This structure reacted in the early stages of the deformation by the concentration of strains in low-angle shear zones which were perhaps controlled in part by pre-existing weak layers such as the marble units. However, the intensity of S fabrics in the mylonitised gneisses is comparable with that in many of the layers of marble, despite the later annealing. This similarity suggests that there appears to have been no obvious lithological control on the siting of these shear zones. Other parts of the complex reacted by folding into major nappes and sheath folds during displacements on the low-angle shear zones. The deformation took place at amphibolite facies conditions as indicated by sillimanite, hornblende and biotite within the mylonites. Many of the minor structures in the mylonites compare closely with the composite contractional and extensional phenomena that formed in sub-horizontal shear zones in Precambrian gneisses in western Norway (Rykkelid \& Fossen, 1992). The S-C fabrics and shear criteria in feldspar porphyroclasts in the mylonites indicate a consistent hanging-wall to the north-east sense of displacement on the low-angle shear zones.

The mylonites and nappes were folded by upright to inclined folds with axes plunging gently north-east or south-west. These folds verge north-west and are associated with south-east dipping thrusts (e.g. Figs 2, 9). A locally intense mineral lineation is coaxial with the folds. This lineation is probably composite because it appears to be partly related to the displacements during the previous period of deformation and it is also an integral part of the youngest deformation as indicated below. The strong elongation of mineral aggregates parallel to the lineation suggests that marked extensions took place parallel to the trend of the Caledonian belt in the Dove Bugt region during the youngest period of ductile deformation in western Dove Bugt (Fig. 3). The fresh, unaltered condition of biotite and hornblende that constitute the linear fabric, and the occurrence of small lenses of anatectic granitic melt coplanar with some of the upright folds indicate that the folding and thrusting took place during amphibolite facies conditions. These conditions are comparable with those of the earlier period of nappes and overthrusting from south-west to north-east. This simi- 
larity suggests that the nappes, overthrusting and younger folds formed during a continuum of mid-crustal deformation.

Fold axes, mineral lineations and the elongation of mineral aggregates in western Dove Bugt have a much greater degree of parallel preferred orientation in the west compared with the east (Fig. 3). For example, fabric data from Edvard $\varnothing$ and Godfred Hansen $\varnothing$ are spread diffusely along broad girdles (Fig. 16), in marked contrast with the clustering of $\mathrm{L}$ fabrics further west (Fig. 3c, f, h). The gneisses on Edvard $\varnothing$ and Godfred Hansen $\varnothing$ are presumed to occur at tectonically higher levels than the tectonic units $\mathrm{A}, \mathrm{B}$ and $\mathrm{C}$, but their detailed relationships with these units are unclear. The change from the more widely dispersed $\mathrm{L}$ fabrics in the east compared with the tight clustering in the west is interpreted in terms of the reorientation of earlier fabrics and fold axes, including perhaps Early Proterozoic phenomena, as the result of an increase in intensity of the youngest deformation from south-east to north-west.

Upright to inclined folds of the youngest period of ductile deformation dominate the structure in the western
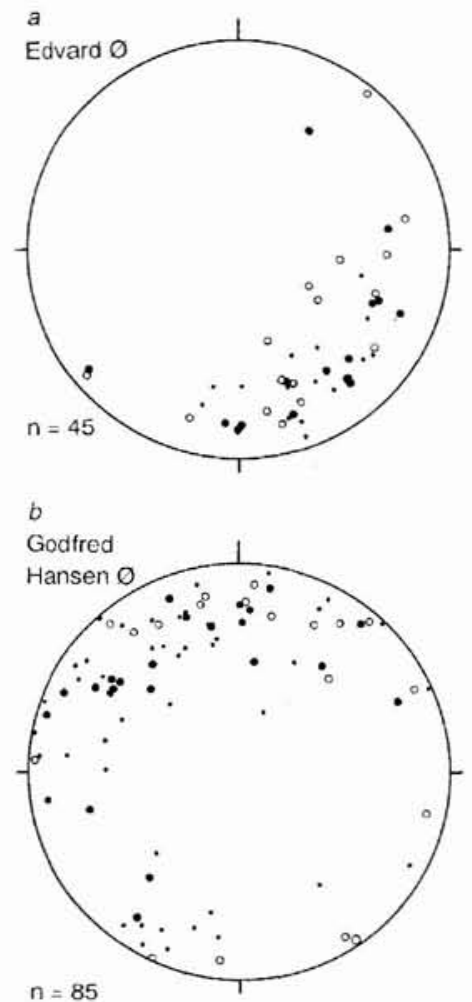

Fig. 16. Equal area stereographic projections of linear data from areas to the east of, and structurally higher than, the tectonic unit $\mathrm{C}$, characterised by mixed orthogneisses. Note the differences in the orientation of the data compared with that from areas further west in Dove Bugt (Fig. 3). part of Dove Bugt. Earlier folds are refolded and highly attenuated, for example, in Daniel Bruun Land (Fig. 13). As the effects of the youngest period of folding are traced across strike, say from Godfred Hansen $\emptyset$ to Kap Stop, the antiforms appear to be preferentially cut out on thrusts compared with the synforms. This effect suggests that the mid-crustal deformation of the Early Proterozoic layercake arrangement of high-grade gneisses in western Dove Bugt yielded a regional composite contractional structure comparable with those on a much smaller scale reported by Rykelid \& Fossen (1992) in the Caledonides of Norway.

\section{Discussion}

Of major importance to the structural interpretation of the Dove Bugt region is an understanding of the timing of the deformation and metamorphism. The key issue in the interpretation of the age of structures in the gneisses of western Dove Bugt is that there is no direct link with known Caledonian phenomena. The complex gneiss terrain in western Dove Bugt is separated from the gneisses and cover rocks in the Caledonian foreland in Dronning Louise Land to the west by wide glaciers feeding from the Inland Ice. Moreover, a Caledonian imbricate thrust zone and the sinistral Storstrømmen shear zone (Figs 1, 17a) in the east of Dronning Louise Land intervene between the gneiss terrain of western Dove Bugt and known Caledonian structures in the foreland rocks to the west (Strachan et al., 1992).

Certain large-scale isoclinal folds may be pre-Caledonian. For example, the isocline which is defined by the amphibolite in the lower limb of the main refolded nappe in north-west Rechnitzer Land (Fig. 4) may be pre-Caledonian on the grounds that the sheet of pink granitic orthogneiss that defines the main nappe is not affected by this early generation of isoclinal folding. We conclude that the principal phase of nappes, their associated mylonites and the upright to inclined folds of the youngest phase with their associated south-easterly dipping thrusts are the effects of Caledonian mid-crustal reactivation of the Early Proterozoic high-grade gneiss complex in western Dove Bugt. Our conclusion is based on the following lines of evidence, although none prove unambiguously a Caledonian age:

(a) A Caledonian age for many of the fabrics is indicated by the cooling age of hornblendes in the gneisses in western Dove Bugt (Dallmeyer \& Strachan, 1994; Dallmeyer et al., 1994). The $c$. 400 Ma metamorphic overprint indicated by SHRIMP U/Pb ages of zircon overgrowths in Early Proterozoic gneisses north of Mørkefjord (Kalsbeek et al., 1993) and similar Sm-Nd ages for 


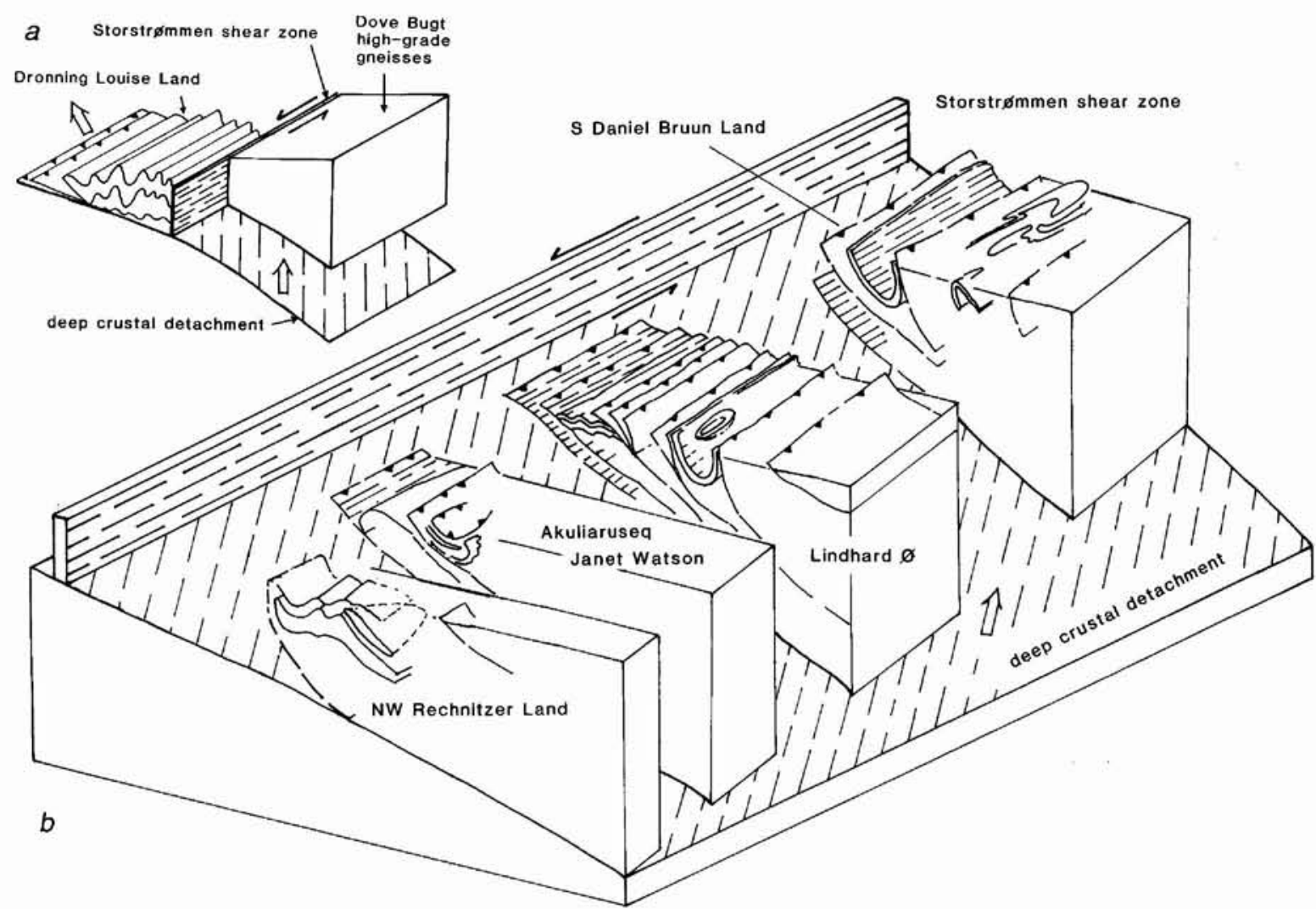

Fig. 17. (a) Large-scale model of the Storstrømmen shear zone from Holdsworth \& Strachan (1991). (b) Large-scale model of the relationships between the structures in the western part of Dove Bugt and the Storstrømmen shear zone.

'eclogitic' pods in Germania Land (Gilotti, 1993, 1994; Brueckner \& Gilotti, 1993) are compatible with amphibolite facies conditions indicated by stable hornblende and sillimanite in the mylonites and anatectic melts associated with folding.

(b) The sequence of deformation is unambiguously younger than the sheets of Early Proterozoic pink granites in western Dove Bugt and it is broadly comparable with the Caledonian sequence in Dronning Louise Land. A top to north-east displacement on the mylonites in western Dove Bugt is compatible with the proven Caledonian north and north-west displacements indicated by structures in Dronning Louise Land as a result of oblique collision with consequent sinistral transpression which was accommodated by the Storstrømmen shear zone (Fig. 17).

(c) The intensity of deformation of the youngest phase of folding increases from south-east to north-west across the Dove Bugt region, i.e. towards the Storstrømmen shear zone.

\section{Relationship of mid-crustal deformation in western Dove Bugt to Caledonian deformation in Dronning Louise Land}

Holdsworth \& Strachan (1991) and Strachan et al. (1992) interpreted the Caledonian structure of Dronning Louise Land (Fig. 1) in terms of a major partitioned system of strike-slip and ductile thrust-slip shear zones that formed in response to sinistral transpression (Fig. 17a). The early phase of Caledonian deformation in Dronning Louise Land gave rise to major low-angle sheath folds with principal transport towards the north. This phase was followed by approximately contemporaneous sinistral displacements on the Storstrømmen shear zone (Fig. 17a), and north-westerly directed thrusting and refolding of the sheath structures. On the grounds of large shortening strains at a high angle to the orogenic trend, Holdsworth \& Strachan (1991) argued that the Storstrømmen shear zone roots into a deep crustal low-angle detachment. The Dove Bugt region east of the Storstrømmen shear zone was believed to have been displaced to the north above this shallow detachment (Fig. 17a) and the final stage of Caledonian deformation in Dronning 
Louise Land involved continued transpression, but with minor local back-collapse on some of the thrusts (Strachan et al., 1992).

The chronology of nappe development, mylonitisation and later folding in western Dove Bugt has many aspects in common with the Caledonian deformation in Dronning Louise Land. Moreover, the north-easterly displacements on the mylonites in the shallow limbs of nappes that are relatively unaffected by later folding in north-west Rechnitzer Land and Akuliaruseq Janet Watson are broadly in accord with the northerly directed displacements on the early sheath folds in Dronning Louise Land. Further east in Dove Bugt, the orientation of linear and other fabric elements is much more irregular (Fig. 16). This irregularity suggests that the nappes further east may have moved in other directions, but details are uncertain because of our limited data.

The nappes and mylonites in western Dove Bugt were folded by upright to inclined folds with north-westerly vergence. These folds indicate significant shortening perpendicular to their north-easterly trend like the later Caledonian folds in Dronning Louise Land. Most of the youngest folds in western Dove Bugt have intense coaxial mineral lineations which are identical to those that appear to be related to the displacement on the earlier mylonites. This relationship suggests that the coaxial lineation formed in part by enhancement (and perhaps some rotation) of the earlier mylonite lineation. Thrusts which are associated with the upright to inclined folds of the youngest phase dip south-east, an orientation which is compatible with their being parts of a deep detachment. The possible relationship between the Storstrømmen shear zone and the presumed Caledonian structures in western Dove Bugt is displayed in Fig. 17b.

\section{Caledonian age of the late extensional structures in western Dove Bugt}

We propose that the final stages of Caledonian deformation in western Dove Bugt are represented by the numerous small-scale extensional structures with downthrow to the north or south (Figs 14, 15). These structures are in the form of small ductile shear zones with broadly east-west strike and steep dip to the south. They are especially common in Daniel Bruun Land. Others are relatively brittle, but they have similar east-west strike and steep dips, although they may be listric, for example, in the gabbro-anorthosite at Kap Stop. The timing of many of the listric structures in outcrops of mylonites is commonly ambiguous because some of them can be correlated with displacements related to the emplacement of the nappes. However, the extensional structures in the Kap Stop gabbro-anorthosite are younger than the Kap
Stop antiform because they have a consistent orientation and downthrow on both limbs. The cumulative extension on these late structures indicates considerable stretching, but of unknown magnitude, parallel to the length of the Caledonian belt in North-East Greenland. It is conceivable that this orogen-parallel extension was related to sinistral wrench faulting and the Caledonian extensional collapse that gave rise to the Devonian basins in NorthEast Greenland (Larsen \& Bengaard, 1991).

\section{Post-Caledonian fractures}

Post-Caledonian fractures are predominantly steep, NW trending joints which form topographic lineaments (Figs $4 a, 9,13)$. One major NW trending fault (Bagfjord fault) is exposed in southern Lindhard $\emptyset$, and another parallel fault is believed to be concealed beneath the waters of Borgfjorden on the grounds of offsets of the principal structures between Lindhard $\varnothing$ and Kap Stop (Fig. 2).

The Bagfjord fault in southern Lindhard $\emptyset$ (Fig. 9) forms a steep zone $c .50 \mathrm{~m}$ wide which is characterised by reddened, epidotised and brecciated gneisses with abundant veins of quartz and carbonate. The fault appears to have a component of dextral displacement of probably no more than 1-2 km on the grounds of the distribution of pink hornblendic orthogneisses on either side of the brecciated zone. No dip-slip component was identified. The topography south of Bræfjorden suggests that the Bagfjord fault extends at least $25 \mathrm{~km}$ south-east into Rechnitzer Land. A sinistral component of displacement is suggested by offsets of regional structures across the postulated Borgfjorden fault (Fig. 2). This fault appears to be part of a system of NW trending fractures which extend south-east across Ad. S. Jensen Land. The importance of these two faults is that they must displace the Storstrømmen shear zone south-eastwards (Fig. 1).

The north-west trend and steep dip of the post-Caledonian fractures in western Dove Bugt suggest that they are part of the major system of NW trending fractures that are common throughout the tract of North-East Greenland between $72^{\circ}$ and $76^{\circ} \mathrm{N}$. Surlyk $(1977 \mathrm{a}, \mathrm{b})$ reported that NW trending normal faults in Wollaston Forland, Hochstetter Forland and elsewhere cut across N-S trending faults which are part of the regional extensional system that controlled Mesozoic basin development north of Scoresby Sund. Torske \& Prestvik (1991) have interpreted some of the NW trending faults, for example, the Kejser Franz Joseph fault, as transfer-faults that linked the N-S trending Mesozoic and Palaeocene rifts in Greenland and Norway prior to sea-floor spreading in the Norwegian-Greenland Sea region. They proposed that the NW trending faults have deep extensions into the lithosphere and argued that the Kejser Franz Joseph fault 
(Fig. 1), which has a continuation with the Jan Mayen fracture zone, controlled the site of local early Eocene alkalic volcanism in North-East Greenland.

The NW trending fractures in western Dove Bugt may be regarded as part of the Mesozoic transfer-fault system in North-East Greenland in accord with the views of Torske \& Prestvik (1991). In Dove Bugt they probably had a close genetic relationship with the $\mathrm{N}-\mathrm{S}$ trending Mesozoic fault on the east coast of Store Koldewey (see also Surlyk, 1977b). It is conceivable that the fluid activity in the NW trending fractures in western Dove Bugt may have had a deep source like those further south. Moreover, localised breccias cutting the gneisses on the large island north of the Bræøerne and some of the grey gneisses with nodular structures enriched in carbonate and fluorite on Lindhard Ø (Chadwick et al., 1990) may also be effects of early Eocene fluid activity within the fracture system.

\section{References}

Brueckner, H. K. \& Gilotti, J. 1993: Preliminary age constraints on the timing of eclogite facies metamorphism, North-East Greenland Caledonides. Abstr. geol. Soc. Amer. 25, A-340 only.

Chadwick, B. \& Friend, C. R. L. 1990: The crystalline rocks of western and southern Dove Bugt, North-East Greenland. Rapp. Grønlands geol. Unders. 148, 127-132.

Chadwick, B. \& Friend, C. R. L. 1991: The high-grade gneisses in the south-west of Dove Bugt: an old gneiss complex in a deep part of the Caledonides of North-East Greenland. Rapp. Gronlands geol. Unders. 152, 103-111.

Chadwick, B., Friend, C. R. L., George, M. C. \& Perkins, W. T. 1993: A new occurrence of musgravitc, a rare beryllium oxide, in the Caledonides of North-East Greenland. Mineralog. Mag. 57, 121-129.

Dallmeyer, R. D. \& Strachan, R. A. $1994:{ }^{40} \mathrm{Ar} /{ }^{39} \mathrm{Ar}$ mineral age constraints on the timing of deformation and metamorphism, North-East Greenland Caledonides. Rapp. Grønlands geol. Unders. 162 (this volume).
Dallmeyer, D., Strachen, R. A. \& Henriksen, N. 1994: ${ }^{40} \mathrm{Ar} \mathbf{r}^{39} \mathrm{Ar}$ mineral age record in NE Greenland - implications for tectonic evolution of the North Atlantic Caledonides. J. geol. Soc. Lond. 151, 615-628.

Gilotti, J. 1993: Discovery of a medium-temperature eclogite province in the Caledonides of North-East Greenland. Geology 21, 523-526.

Gilotti, J. 1994: Eclogites and related high-pressure rocks from North-East Greenland. Rapp. Gronlands geol. Unders. 162 (this volume).

Holdsworth, R. E. \& Strachan, R. A. 1991: Interlinked system of ductile strike-slip and thrusting formed by Caledonian sinistral transpression in northeastern Greenland. Geology 19, 510-513.

Kalsbeek, F., Nutman, A. P. \& Taylor, P. N. 1993: Palaeoproterozoic basement province in the Caledonian fold belt of NorthEast Greenland. Precambrian Res. 63, 163-178.

Larsen, P.-H. \& Bengaard, H.-J. 1991: Devonian basin initiation in East Greenland: a result of sinistral wrench faulting and Caledonian extensional collapse. J. geol. Soc. Lond. 148, 355-368.

Rykkelid, E. \& Fossen, H. 1992: Composite fabrics in midcrustal gneisses: observations from the Oygarden Complex, West Norway Caledonides. J. struct. Geol. 14, 1-10.

Schmid, S. M., Paterson, M. S. \& Boland, J. N. 1980: High temperature flow and dynamic recrystallisation in Carrara Marble. Tectonophysics 65, 245-280.

Strachan, R. A., Holdsworth, R. E., Friderichsen, J. D. \& Jepsen, H.F. 1992: Regional Caledonian structure within an oblique convergence zone, Dronning Louise Land, NE Greenland. $J$. geol. Soc. Lond. 149, 359-371.

Surlyk, F. 1977a: Stratigraphy, tectonics and palaeogeography of the Jurassic sediments of the areas of Kong Oscars Fjord, East Greenland. Bull. Gronlands geol. Unders. 123, 56 pp.

Surlyk, F. 1977b: Mesozoic faulting in East Greenland. Geol. Mijnb. 56, 311-327.

Torske, T. \& Prestvik, T. 1991: Mesozoic detachment faulting between Greenland and Norway: inferences from Jan Mayen Fracture Zone system and associated alkali rocks. Geology 19, 481-484.

Tucker, R. D., Dallmeyer, D. \& Strachan, R. A. 1993: Age and tectonothermal record of Laurentian basement, Caledonides of NE Greenland. J. geol. Soc. Lond. 150, 371-379. 